\title{
Kardiální varianta Fabryho choroby manifestující se jako hypertrofická kardiomyopatie s těžkou mid-ventrikulární obstrukcí
}

\author{
Tomáš Paleček, Sudheera Magage, Lubor Goláň, Gabriela Dostálová, Milan Elleder*, Miroslava Buchtová**, \\ Aleš Linhart \\ 2. interní klinika kardiologie a angiologie, *Ústav dědičných metabolických poruch, Všeobecná fakultní nemocnice \\ a 1. lékařská fakulta Univerzity Karlovy, Praha, **Interní a kardiologická ambulance, Otrokovice, Česká republika
}

Autoři představují případ 55letého muže, který byl pro palpitační obtíže v roce 2003 vyšetřen kardiologem v místě svého bydliště. Echokadiograficky byla zjištěna hypertrofie levé komory, která byla hodnocena, vzhledem k absenci anamnézy arteriální hypertenze, jako obraz hypertrofické kardiomyopatie; dále byl popsán myxom levé síně. Ve stejném roce nemocný podstoupil úspěšné chirurgické odstranění atriálního tumoru v regionálním kardiocentru. Od té doby byl nadále $\mathrm{v}$ péči kardiologa a léčen beta-blokátorem. V roce 2005, na základě informace o zahájení celorepublikového screeningu Fabryho choroby u mužů s nevysvětlitelnou hypertrofií levé komory v časopise Cor et Vasa (studie FACSS), ${ }^{(1)}$ byl nemocný odeslán $\mathrm{k}$ vyšetření na naše pracoviště. Echokardiograficky jsme zjistili těžkou koncentrickou hypertrofii levé komory se zachovalou ejekční frakcí (obrázek 1),

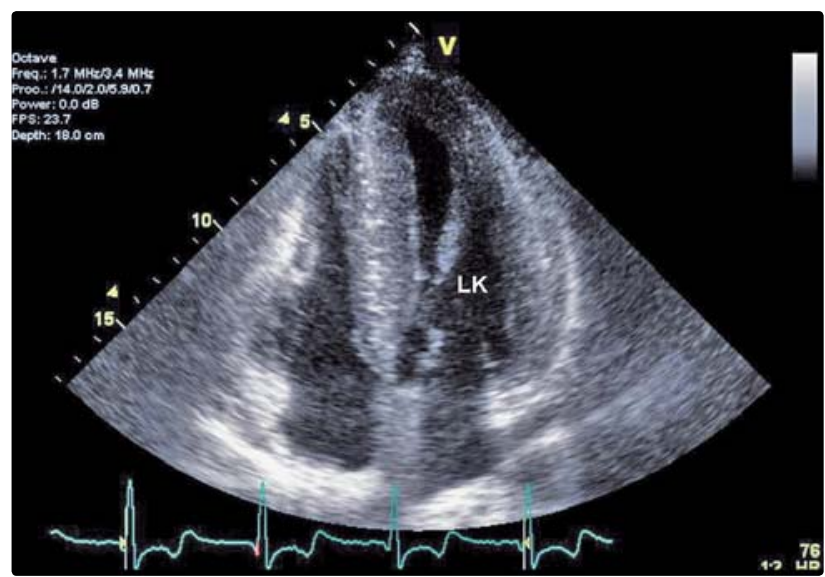

Obrázek 1 Transthorakální echokardiografické vyšetření: v apikální čtyřdutinové projekci je patrna těžká koncentrická hypertrofie levé komory

LK - levá komora ale sníženou systolickou deformací myokardu podle 2D strain analýzy (obrázek 2), těžkou diastolickou dysfunkcí restriktivního typu a významnou mid-ventrikulární dynamickou obstrukcí v důsledku hypertrofie papilárních svalů (vrcholový gradient v klidu $100 \mathrm{~mm} \mathrm{Hg),} \mathrm{viz} \mathrm{obrázky} 3$ a 4. Biochemická vyšetření prokázala výrazně sníženou plazmatickou aktivitu a-galaktosidázy A a zvýšenou koncentraci globotriaosylceramidu v moči. Výsledky dalších vyšetření neprokázaly postižení jiných orgánů, především nebyly přítomny kožní manifestace Fabryho choroby a renální postižení, včetně absence proteinurie. Genetické vyšetření potvrdilo prítomnost mutace $c[801+48 \mathrm{~T}>\mathrm{G}]$ genu pro a-galaktosidázu A. Finálně byla stanovena diagnóza tzv. kardiální formy Fabryho choroby a zahájena enzymatická substituční léčba (Fabrazyme $)^{\oplus}$.

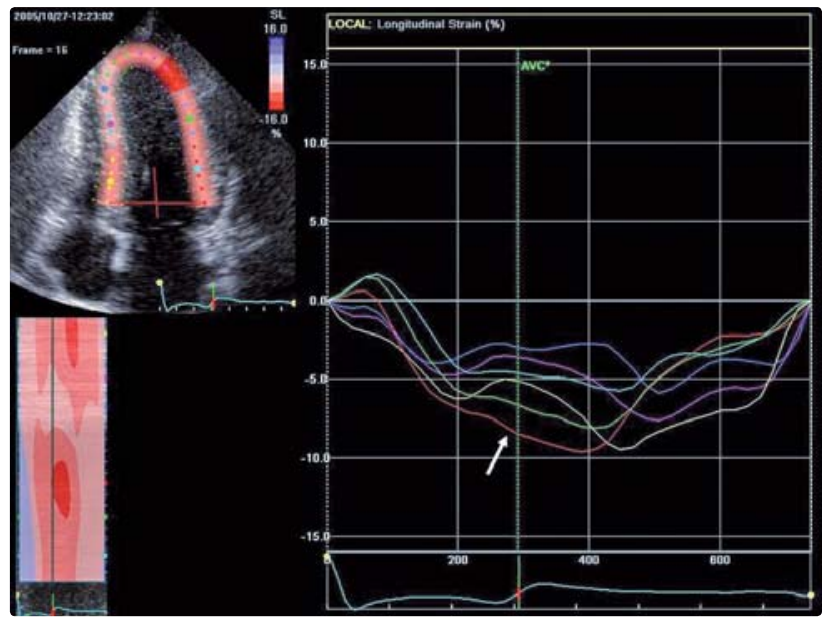

Obrázek 2 Transthorakální echokardiografické vyšetření: 2D strain analýza v apikální čtyřdutinové projekci, prokazující snižené hodnoty vrcholové systolické deformace myokardu levé komory (šipka) 


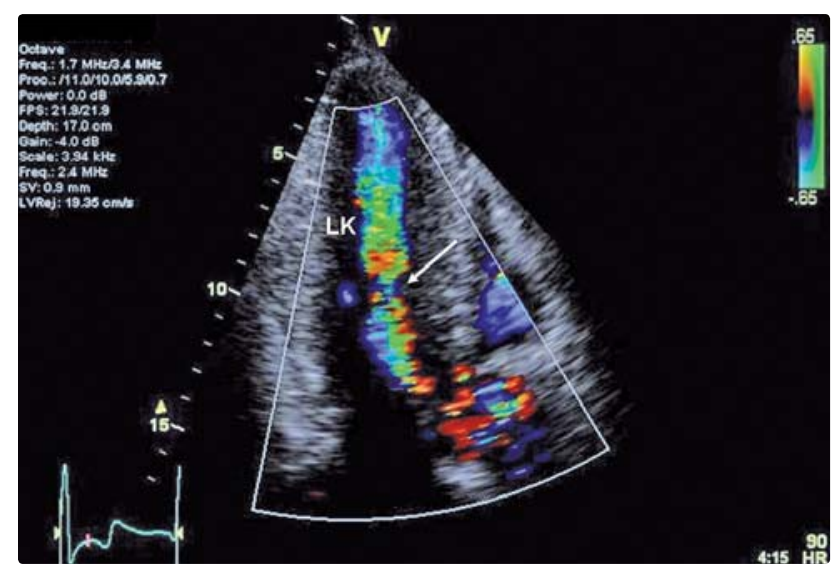

Obrázek 3 Transthorakální echokardiografické vyšetření: při použiti barevného dopplerovského mapování je v apikální projekci na dlouhou osu patrna turbulence proudění vznikající uprostřed dutiny levé komory, ukazující na přítomnost mid-ventrikulární obstrukce (šipka)

LK - levá komora

Fabryho choroba je na chromosom $\mathrm{X}$ vázané onemocnění podmíněné deficientní aktivitou lysosomálního enzymu a-galaktosidázy A, která vede ke střádání glykosfingolipidů v řadě tkání a orgánů. Klinické manifestace jsou četné, typické jsou projevy kožní (tzv. angiokeratomata), postižení renální, neurologické a kardiální. Charakteristickou kardiální manifestací je hypertrofie levé komory. ${ }^{(2)}$ Opakovaně byla popsána tzv. kardiální varianta onemocnění, kdy jediným projevem choroby je hypertrofie levé komory. Hypertrofie levé komory na podkladě Fabryho choroby se podle současných pozorování vyskytuje přibližně u 1-3\% jedinců vedených pod diagnózou hypertrofické kardiomyopatie..$^{(3-5)}$

Námi uvedený případ demonstruje důležitost systematického screeningu Fabryho choroby u všech nemocných s jinak nevysvět-

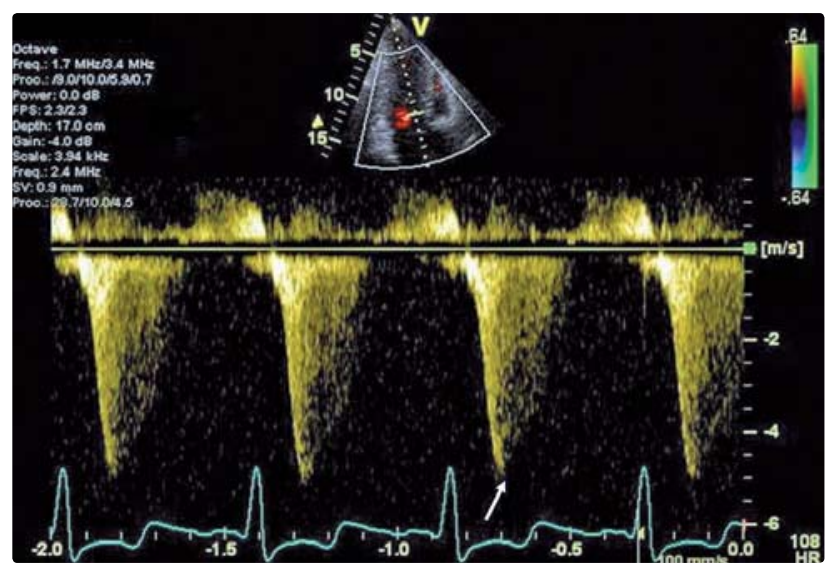

Obrázek 4 Transthorakální echokardiografické vyšetření: kontinuálně dopplerovská analýza kvantifikující významnou mid-ventrikulární obstrukci levé komory s maximálním intraventrikulárním tlakovým gradientem zhruba $100 \mathrm{~mm} \mathrm{Hg}$ (šipka)

litelnou hypertrofií levé komory, včetně raritních forem, jako je např̀. mid-ventrikulární dynamická obstrukce.

\section{Literatura}

1. Paleček T, Linhart A, Magage S, et al. Multicentrický screening Fabryho choroby u jedinců s nevysvětlitelnou hypertrofí levé komory. FACSS-desing studie. Cor Vasa 2005;47:242-5.

2. Paleček T, Lubanda JC, Magage $S$, et al. Kardiální manifestace Fabryho choroby: současné znalosti. Vnitř Lék 2004;50:846-51.

3. Nakao S, Takenaka T, Maeda M, et al. An atypical variant of Fabry's disease in men with left ventricular hypertrophy. N Engl J Med 1995;333:288-93.

4. Sachdev B, Takenaka T, Teraguchi $\mathrm{H}$, et al. Prevalence of Anderson-Fabry disease in male patients with late onset hypertrophic cardiomyopathy. Circulation 2002;105:1407-11.

5. Monserrat L, Gimeno-Blanes JR, Marin F, et al. Prevalence of Fabry disease in a cohort of 508 unrelated patients with hypertrophic cardiomyopathy. J Am Coll Cardiol 2007;50:2399-403. 